\title{
Spinal Nerve Plexus
}

National Cancer Institute

\section{Source}

National Cancer Institute. Spinal Nerve Plexus. NCI Thesaurus. Code C49601.

Any one of the four networks of intersecting nerves originating from the spinal cord,

which transmit motor, sensory, and autonomic signals between the spinal cord and the body. 